\title{
Prevalensi dan Distribusi Faktor Risiko Depresi pada Lansia di Wilayah Kerja Puskesmas Tampaksiring I Kabupaten Gianyar Bali 2015
}

\author{
Anak Agung Ngurah Aryawangsa ${ }^{1}$, Ni Luh Putu Ariastuti ${ }^{2}$ \\ ${ }^{1}$ Program Studi Pendidikan Dokter, Fakultas Kedokteran Universitas Udayana \\ ${ }^{2}$ Bagian IImu Kedokteran Komunitas dan IImu Kedokteran Pencegahan \\ FK Universitas Udayana/RSUP Sanglah
}

\begin{abstract}
Diterima: 26 Mei 2016. Disetujui: 6 Juni 2016. Diterbitkan: Agustus 2016
\section{ABSTRAK}

Seiring dengan peningkatan derajat kesehatan dan kesejahteraan penduduk akan berpengaruh pada peningkatan usia harapan hidup yang menyebabkan terjadinya peningkatan jumlah populasi lanjut usia (lansia). Pada lansia, terjadi proses penuaan, hal ini menyebabkan perubahan pada fisik dan mental seorang individu. Di samping itu terjadi pula perubahan lingkungan sosioekonomi seperti berhenti bekerja, kehilangan orang yang dicinta, dan sebagainya yang dapat mengakibatkan lansia menjadi lebih rentan untuk mengalami masalah depresi. Kejadian depresi pada lansia seringkali diabaikan akibat kurangnya perhatian dari keluarga atau sanak saudara, padahal dampak depresi pada lansia sangat buruk dan apabila tidak tertangani dapat mengurangi kualitas hidup dan meningkatkan angka kematian. Melihat pentingnya masalah ini, penulis melakukan penelitian untuk mengetahui gambaran faktor risiko kejadian depresi pada lansia di wilayah kerja Puskesmas Tampaksiring I sebagai langkah advokasi dalam usaha peningkatan program-program promotif dan preventif dalam menghadapi permasalahan lansia di wilayah kerja Puskesmas Tampaksiring I. Penelitian ini merupakan penelitian deskriptif cross-sectional yang dilakukan pada bulan April-Mei 2015. Sampel dalam penelitian adalah lansia berusia 60 tahun keatas dengan jumlah sampel sebanyak 90 orang yang dipilih secara acak pada desa di wilayah kerja Puskesmas Tampaksiring I Kabupaten Gianyar dengan menggunakan teknik multistage random sampling. Data diperoleh dengan melakukan wawancara terhadap responden menggunakan kuesioner terstruktur. Hasil penelitian menunjukkan bahwa prevalensi depresi pada lansia sebesar $23,3 \%$. Kejadian depresi cenderung dialami oleh laki-laki $(30,6 \%)$, kelompok usia $\geq 70$ tahun $(30,6 \%)$, tingkat pendidikan rendah $(24,4 \%)$, tidak bekerja $(25,4 \%)$, tingkat penghasilan perbulan rendah $(41,2 \%)$, tidak menikah (50\%), memiliki penyakit kronis $>2(28,6 \%)$, dan tidak memiliki riwayat keluarga depresi $(23,9 \%)$. Prevalensi lansia dengan depresi cenderung lebih tinggi pada lansia laki-laki, kelompok usia 70 tahun ke atas, berpendidikan rendah, tidak bekerja, berpenghasilan perbulan rendah, tidak menikah, memiliki penyakit kronis $>2$, dan tidak memiliki riwayat keluarga depresi.
\end{abstract}

Kata kunci: depresi, lansia, Puskesmas Tampaksiring I, Desa Tampaksiring, Desa Sanding

PREVALENCE AND RISK FACTORS DISTRIBUTION OF DEPRESSION IN ELDERLY AT TAMPAKSIRING I PRIMARY HEALTH CARE GIANYAR REGENCY BALI 2015

\section{ABSTRACT}

Along with improving health and well-being of the population will affect the increase in life expectancy so that an increasing number of the elderly population. In the elderly, the aging process occurs, it causes changes in an individual's physical and mental status. In addition, there were also changes in the socioeconomic environment such as stop working, the lost of a beloved one, which can lead the elderly to become more prone to experiencing depression problems. The incidence of depression in the elderly is often overlooked due to lack of attention from family or relatives, 
whereas the impact of depression in the elderly is very bad and if untreated can reduce quality of life and increased mortality. Seeing the importance of this issue, the authors wanted to make research to describe the risk factors of depression incidence in the elderly in Puskesmas Tampaksiring I as a step in efforts to increase advocacy programs of promotion and prevention in dealing with problems of the elderly in Puskesmas Tampaksiring I. This study was a descriptive cross-sectional study that carried out in April-May 2015. The sample in the study were elderly aged 60 years and older with a total sample of 90 randomly selected people in the villages served by Puskesmas Tampaksiring I, Gianyar using multistage random sampling technique. Data were obtained by conducting interviews with respondents using a structured questionnaire. The results of this study indicate that the prevalence of depression in the elderly by $23.3 \%$. The incidence of depression tend to be experienced by men $(30.6 \%), \geq 70$ years age group (30.6\%), low educational level $(24.4 \%)$, not working $(25.4 \%)$, monthly income level is low (41.2\%), not married (50\%), having $>2$ chronic diseases $(28.6 \%)$, and doesn't have family depression history (23.9\%). The prevalence of elderly with depression is more likely higher in elderly males, age group 70 years and older, less educated, not working, low monthly income, not married, more than two chronic diseases, and doesn't have family depression history.

Keywords: depression, elderly, Puskesmas Tampaksiring I, Tampaksiring Village, Sanding Village

\section{PENDAHULUAN}

Sejalan dengan peningkatan derajat kesehatan dan kesejahteraan penduduk akan berpengaruh pada peningkatan usia harapan hidup. Peningkatan usia harapan hidup ini menjadi salah satu indikator penentu keberhasilan program pembangunan suatu negara. Namun peningkatan usia harapan hidup ini dapat menyebabkan adanya perubahan struktur demografi dimana terjadinya peningkatan jumlah populasi yang tergolong lanjut usia (lansia) setiap tahunnya. Berdasarkan Undang-Undang No 13 Tahun 1998 tentang kesejahteraan lansia, ditetapkan bahwa batasan umur lansia di Indonesia adalah 60 tahun ke atas. ${ }^{1}$ Jumlah penduduk lansia di Indonesia pada tahun 2006 sebesar kurang lebih 19 juta jiwa, kemudian meningkat menjadi 23,9 juta $(9,77 \%)$ pada tahun 2010. Badan Pusat Statitik (BPS) memperkirakan jumlah lansia pada tahun 2020 akan mencapai 28,8 juta jiwa atau $11,34 \%$ dari jumlah penduduk Indonesia. ${ }^{1} \mathrm{Hal}$ ini menjadikan Indonesia sebagai Negara tertinggi dalam pertumbuhan penduduk lanjut usia dimana terjadi kenaikan populasi lansia sebesar $414 \%$ dalam kurun waktu 1990-2010.2

Peningkatan jumlah lansia juga terjadi di Provinsi Bali, dimana pada tahun 2006 sebesar 7,2\% menjadi $8,7 \%$ pada tahun 2010 , dan meningkat menjadi $9,4 \%$ dari total penduduk pada tahun $2011 .^{3}$ Di samping itu, perubahan demografis juga terjadi di wilayah kerja Puskesmas Tampaksiring I, dimana terjadi peningkatan prorposi lansia secara progresif. Proporsi lansia di wilayah kerja Puskesmas Tampaksiring I pada tahun 2014 mencapai $12 \%$ dari total penduduk, lebih tinggi jika dibandingkan dengan proporsi nasional lansia tahun 2013 yakni sebesar $11,5 \%{ }^{4}$

Dalam pelaksanaannya, program lansia di Puskesmas Tampaksiring I masih belum menjadi sebuah program yang diprioritaskan. Hal ini ditunjukkan dari pelaksanaan program posyandu lansia pada tahun 2014 yang hanya diikuti oleh 2,5\% dari total populasi lansia di wilayah kerja Puskesmas Tampaksiring I. Angka tersebut diakibatkan oleh karena dari 33 posyandu lansia yang ada, hanya 1 posyandu lansia dengan jumlah 77 orang anggota yang masih aktif dalam melaksanakan kegiatannya sesuai dengan program. Hal ini tentunya menyebabkan banyaknya program kesehatan lansia yang tidak mencapai sasaran. Hal ini menggambarkan belum tercapainya tujuan khusus dari program lansia Puskesmas Tampaksiring I yang salah satunya bertujuan untuk meningkatkan kualitas hidup dari lansia, dimana salah satu poin penting penyusun layaknya kualitas hidup seseorang adalah aspek kesehatan mental.

Pada hakikatnya penuaan merupakan serangkaian proses alami yang tidak dapat dihindari, berjalan terus menerus, dan berkesinambungan, $\mathrm{Hal}$ ini menyebabkan perubahan pada fisik dan mental seorang individu yang mengalami proses penuaan. Di samping itu, perubahan lingkungan sosial para lansia juga terus terjadi seperti ketidakmampuan 
ekonomi, ketiadaan sanak saudara yang dapat memberi bantuan, berhenti bekerja, peningkatan risiko terkena penyakit, kehilangan anggota keluarga, serta ketidakmampuan untuk berperan lagi di masyarakat. Beragam perubahan kondisi tersebut mengakibatkan lansia menjadi lebih rentan untuk mengalami masalah mental. ${ }^{5}$ Depresi merupakan gangguan mental yang paling sering terjadi pada lansia. ${ }^{6}$ Akan tetapi kejadian depresi pada lansia seringkali diabaikan akibat kurangnya perhatian dari masyarakat, sehingga seringkali depresi pada lansia tidak terdeteksi, salah didiagnosis, atau tidak ditangani dengan baik. Dampak depresi pada lansia sangatlah buruk. Keadaan depresi yang tidak tertangani dengan baik menyebabkan peningkatan penggunaan fasilitas kesehatan dan medis, mengurangi kualitas hidup, dan kematian. ${ }^{7}$

Data insidens depresi di Indonesia sangat bervariasi dan berbeda di masing-masing daerah penelitian. Salah satu penelitian menyatakan bahwa angka depresi pada lansia di Indonesia sebesar $6,5 \%^{8}$, sedangkan angka depresi pada lansia yang menderita suatu penyakit cenderung lebih tinggi, yakni sekitar 12-24\%. Database laporan kesehatan Provinsi Bali maupun kabupaten di Bali tidak mencatat mengenai angka depresi di Bali, akan tetapi apabila kita asumsikan bahwa 6,5\% lansia menderita depresi, maka pada tahun 2010 dimana jumlah lansia di Bali sebesar 380.114 orang ${ }^{3}$ diperkirakan terdapat sebanyak 24.700 orang lansia di Bali yang mengalami depresi.

Berdasarkan observasi dan hasil wawancara dengan pemegang program Posyandu Lansia Puskesmas Tampaksiring I, diperoleh bahwa terdapat cukup banyak lansia yang mengalami gejala-gejala perubahan kondisi mental yang mengarah kepada depresi. Dikatakan bahwa sebagian besar lansia yang mengalami gejala tersebut akibat memiliki kendala akibat perubahan lingkungan sosialnya. Kehilangan pasangan dan ketidakmampuan lagi dalam bekerja dan terliba dalam kegiatan sosial akibat usia maupun penyakit diperkirakan menjadi penyebab para lansia menjadi rentan mengalami depresi. Akan tetapi kondisi ini seringkali diabaikan penderita dan keluarga sehingga tidak menjadi keluhan saat melakukan pemeriksaan kesehatan.

Kerentanan terhadap depresi pada lansia disebabkan baik oleh faktor internal maupun eksternal. Kondisi lansia yang mengalami penyakit kronis dan berbagai pengobatan juga semakin meningkatkan angka kejadian depresi pada lansia. Berdasarkan data yang diperoleh pada kegiatan Posyandu lansia Puskesmas Tampaksiring I selama tahun 2014 didapatkan sebesar 31\% lansia memiliki setidaknya satu penyakit kronis yang memerlukan pengobatan berkelanjutan. Diperkirakan angka ini lebih besar apabila semua lansia di wilayah kerja tersebut diskrining secara keseluruhan. Kehilangan pekerjaan, penghasilan, dan dukungan sosial sejalan dengan bertambahnya usia dan penyakit turut menjadi faktor predisposisi yang memudahkan seorang lansia untuk mengalami depresi. ${ }^{5}$ Berdasarkan studi yang telah dilakukan, beberapa faktor yang berhubungan dengan kejadian depresi pada lansia antara lain: usia, jenis kelamin, riwayat keluarga depresi, riwayat penyakit, tingkat pendidikan, status perkawinan, status pekerjaan, dan penghasilan keluarga.

Di Puskesmas Tampaksiring I, belum ada data penelitian mengenai prevalensi dan faktor risiko yang berhubungan dengan kejadian depresi pada lansia di daerah tersebut. Pada Laporan Tahunan Program Lansia Puskesmas Tampaksiring I tahun 2014 juga tidak dijelaskan mengenai upaya pada program puskesmas dalam mendeteksi maupun menangani kejadian depresi pada lansia, sehingga angka kejadian depresi di daerah tersebut masih belum diketahui.

Berdasarkan permasalahan tersebut dan dalam upaya peningkatan derajat kesehatan masyarakat utamanya lansia maka diperlukan suatu penelitian mengenai distribusi faktor risiko yang berhubungan dengan kejadian depresi pada lansia di wilayah kerja Puskesmas Tampaksiring I sebagai langkah advokasi dalam usaha peningkatan programprogram promotif dan preventif dalam menghadapi permasalahan lansia di wilayah kerja Puskesmas Tampaksiring I pada umumnya.

\section{METODE PENELITIAN}

\section{Rancangan Penelitian}

Jenis penelitian yang dipergunakan adalah studi deskriptif kuantitatif dengan pendekatan cross sectional.

\section{Tempat dan Waktu Penelitian}

Penelitian dilaksanakan di wilayah kerja Puskesmas Tampaksiring I, Kecamatan Tampaksiring pada bulan April-Mei tahun 2015. 
Pemilihan secara acak ini dilakukan dengan

\section{Populasi dan Sampel}

Populasi dalam penelitian ini adalah seluruh lanjut usia yaitu mereka yang berusia 60 tahun atau lebih yang bertempat tinggal di wilayah kerja Puskesmas Tampaksiring I, Kecamatan Tampaksiring. Jumlah keseluruhan lansia meurut Profil UPT Kesmas Tampaksiring I tahun 2014 sebanyak 3079 jiwa.

Besar sampel dihitung dengan menggunakan rumus berikut:

$$
\mathrm{n}=\frac{\mathrm{z} \alpha^{2}(\mathrm{pq})}{\mathrm{d}^{2}}
$$

Keterangan:

$\mathrm{n}$ : jumlah sampel yang diperlukan

za:deviat baku, digunakan 1,96 pada confidence interval 95\%

$\mathrm{p}: 60 \%$ yaitu proporsi lansia yang mengalami depresi $^{9}$

$q: 1$ - $p$, didapatkan $40 \%(0,40)$

$\mathrm{d}$ : deviasi yang diinginkan / bisa ditoleransi, digunakan $10 \%(0,1)$

Perhitungan jumlah sampel yang diperlukan:

$$
\begin{gathered}
n=\frac{(1,96)^{2}(0,60 \times 0,40)}{(0,1)^{2}} \\
n=92,198 \text { orang } \\
n=92 \text { orang }
\end{gathered}
$$

Populasi lanjut usia di wilayah kerja Puskesmas Tampaksiring I, Kecamatan Tampaksiring berjumlah kurang dari 100.000 orang, sehingga dapat dilakukan koreksi jumlah sampel dengan menggunakan rumus berikut:

$$
\mathrm{nK}=\frac{\mathrm{n}}{1+{ }^{\mathrm{n} / \mathrm{N}}}
$$

Keterangan:

nK : jumlah sampel setelah dikoreksi

$\mathrm{n}$ : jumlah sampel sebelum dikoreksi

$\mathrm{N}$ : jumlah populasi

$$
\begin{gathered}
n K=\frac{92}{1+92 / 3079} \\
\mathrm{nK}=89,330 \text { orang } \\
\mathrm{nK}=89 \text { orang }
\end{gathered}
$$

Dari perhitungan di atas diperoleh jumlah sampel minimal yang diperlukan adalah sebanyak 89 orang. Dalam penelitian ini kami menggunakan sampel sebanyak 90 orang.

Sampel dalam penelitian ini diambil dengan menggunakan sistem multistage random sampling. Langkah pertama dipilih dua dari tiga desa yang ada di wilayah kerja Puskesmas Tampaksiring I. mengundi nama-nama desa yang sudah ditulis dalam selembar kertas. Dari pengundian ini terpilih dua desa, yaitu Desa Tampaksiring dan Desa Sanding. Selanjutnya, dari tiga belas banjar yang ada di Desa Tampaksiring tersebut, dipilih dua banjar secara acak seperti cara sebelumnya. Banjar yang terpilih adalah Banjar Eha dan Banjar Tengah. Di Desa Sanding dilakukan hal yang sama, hanya saja pada Desa Sanding hanya dipilih satu Banjar secara acak. Banjar yang terpilih dari Desa Sanding adalah Banjar Sanding Bitra. Kemudian data lansia yang diperoleh dari register banjar tersebut diurutkan sebagai sampling frame, dilanjutkan dengan pemilihan sampel secara acak dengan menggunakan tabel random hingga jumlah sampel yang diperlukan terpenuhi.

\section{Variabel Penelitian}

Variabel dalam penelitian adalah sebagai berikut:
1. Umur
2. Jenis kelamin
3. Tingkat pendidikan
4. Status pernikahan
5. Status pekerjaan
6. Penghasilan keluarga perbulan
7. Riwayat keluarga depresi
8. Riwayat penyakit
9. Kejadian depresi

\section{Definisi Operasional Variabel Penelitian}

1. Usia ditentukan dari lama hidup lansia yang dihitung dari tanggal lahir hingga tanggal pengambilan data. Tanggal lahir diperoleh dari wawancara langsung pada responden, atau jika responden tidak ingat dapat dilihat dari KTP. Variabel usia dikategorikan ke dalam kelompok usia 60-64 tahun, 65-69 tahun, dan $\geq 70$ tahun

2. Jenis kelamin adalah identitas seksual responden sejak lahir yang tertulis pada KTP atau didapatkan dari wawancara.

3. Tingkat pendidikan adalah jenjang pendidikan formal tertinggi yang dicapai oleh responden. Dikategorikan menjadi rendah (tidak sekolah, tidak tamat SD, tamat SD), sedang (SMP-SMA), dan tinggi (PT).

4. Status pernikahan dikategorikan menjadi tidak menikah, duda/janda, dan menikah (masih memiliki pasangan). 
5. Status pekerjaan merupakan ada atau tidaknya aktifitas rutin yang menghasilkan uang yang dilakukan oleh responden saat ini. Dikategorikan menjadi bekerja dan tidak bekerja.

6. Penghasilan keluarga perbulan adalah Tingkat penghasilan/pendapatan keluarga perbulan berdasarkan garis kemiskinan dengan pendekatan standar minimal pendapatan keluarga sesuai dengan UMK (Upah Minimum Kabupaten). Dikategorikan menjadi dibawah UMK dan diatas UMK, dimana UMK kabupaten Gianyar tahun 2015 sebesar Rp.1.707.750,00

7. Riwayat keluarga depresi didefinisikan sebagai Riwayat keluarga yang memiliki hubungan darah dengan responden yang memiliki riwayat depresi.

8. Riwayat penyakit kronis merupakan ada atau tidaknya penyakit kronis yang diderita oleh responden yang telah didiagnosis oleh dokter dan telah diderita minimal selama tiga bulan. Yang termasuk dalam riwayat penyakit ini antara lain: hipertensi, diabetes melitus, stroke, insomnia, dan penyakit kronis lainnya.. Dikategorikan menjadi 0-2 penyakit dan $>2$ penyakit.

9. Kejadian depresi merupakan suatu gangguan mental umum yang ditandai dengan mood tertekan, hilangnya kesenangan atau minat, perasaan bersalah atau harga diri rendah, gangguan makan atau tidur, turunnya energi dan konsentrasi Diagnosis depresi ditegakkan berdasarkan adanya gejala depresi yang signifikan berdasarkan GDS-15. Dikategorikan menjadi depresi dan tidak depresi

\section{Instrumen Penelitian}

1. Kuesioner untuk mencatat karakteristik dasar yang meliputi usia, jenis kelamin, riwayat penyakit, tingkat pendidikan, status pernikahan, status pekerjaan, penghasilan keluarga perbulan, dan riwayat keluarga depresi.

2. Kuesioner Geriatric Depression Scale (GDS) yang digunakan untuk menilai kejadian depresi pada lansia. Kuesioner ini terdapat dalam dua versi, yaitu versi pendek dengan 15 item pertanyaan dan versi panjang dengan 30 item pertanyaan. Dalam penelitian ini, kami menggunakan kuesioner GDS versi pendek (GDS-15) dengan pertimbangan waktu yang diperlukan untuk melengkapi kuesioner ini lebih singkat dan pertanyaannya yang lebih sederhana. Selain itu juga bertujuan untuk munculnya kejenuhan maupun teralihnya perhatian dalam menjawab pertanyaan kuesioner. Tiap pertanyaan dapat dijawab dengan pilihan "ya" atau "tidak", yang akan memberikan satu poin pada salah satu pilihan jawaban tersebut. Pertanyaan pada nomor 1, 5, 7, 11, dan 13 akan mendapatkan nilai 0 apabila dijawab "ya", sedangkan apabila dijawab "tidak" mendapat nilai 1 . Sistem penilaian ini berlaku sebaliknya untuk 10 pertanyaan lainnya. Kemudian semua nilai dijumlahkan dan diinterpretasikan menjadi, skor 0-4 menunjukkan tidak depresi dan skor $\geq 5$ mengindikasikan depresi. Kuesioner ini juga telah tersedia dalam Bahasa Indonesia, sehingga peneliti tidak lagi menerjemahkan sendiri kuesioner ini ataupun melakukan uji validitas dan reliabilitas.

\section{Cara Pengumpulan Data}

Pengumpulan data dilakukan oleh peneliti dengan mewawancarai responden dengan mengacu pada kuesioner yang telah disiapkan. Sebelum memulai wawancara, responden ditanyakan terlebih dahulu mengenai kesediaannya untuk terlibat dalam peneltian ini dengan memberikan informed consent secara lisan. Dalam sekali wawancara diperkirakan menghabiskan waktu sekitar 15 menit. Wawancara dilakukan berdasarkan atas pertanyaan-pertanyaan pada kuesioner yang meliputi seluruh variabel yang diteliti pada responden dalam penelitian ini.

\section{Analisis Data}

Data yang diperoleh kemudian diolah dengan bantuan perangkat lunak komputer. Data tersebut kemudian dianalisis secara deskriptif kuantitatif (persentase).

\section{Analisis Univariat}

Analisis ini dilakukan untuk membuat gambaran distribusi frekuensi setiap variabel penelitian. Hasil analisis univariat ini disajikan dalam bentuk tabel dan narasi.

\section{Analisis Bivariat}

Analisis ini dilakukan dengan menggunakan tabulasi silang, yaitu antara variabel usia, jenis kelamin, tingkat pendidikan, status pernikahan, status pekerjaan, penghasilan keluarga perbulan, riwayat keluarga depresi, dan riwayat penyakit dengan variabel kejadian depresi.

\section{HASIL PENELITIAN}

Karakteristik Sosiodemografi Responden 
Persebaran responden berdasarkan usia didominasi oleh kelompok usia 70 tahun atau lebih yaitu sebesar 49\%, diikuti oleh kelompok usia 60-64 tahun dan kelompok usia 65-69 tahun. Berdasarkan kategori jenis kelamin, didominasi oleh responden perempuan. Dimana perempuan sebanyak $60 \%$ dan laki-laki sebesar $40 \%$ dari total responden. Mayoritas responden memiliki tingkat pendidikan yang tergolong rendah yaitu sebanyak $95,6 \%$ disusul dengan pendidikan sedang sebanyak 4 orang $(4,4 \%)$ dan tidak ada responden yang tergolong pada pendidikan tinggi. Berdasarkan status pernikahan, proporsi responden yang menikah ditemukan paling tinggi yaitu sebesar $63,3 \%$, diikuti oleh duda/janda sebesar 32,2\%, dan tidak menikah sebesar $4,4 \%$. Ditinjau dari status pekerjaan saat ini sebanyak 63 orang $(70 \%)$ responden berada pada status sudah tidak bekerja. Melalui wawancara mengenai ratarata penghasilan keluarga responden perbulan, ditemukan lebih banyak responden yang berpenghasilan diatas Upah Minimum Kabupaten (UMK) yakni sebanyak $62,2 \%$, sedangkan sisanya sebanyak 34 responden (37,8\%) berpenghasilan dibawah UMK. Karakteristik Responden dapat dilihat pada Tabel 1.

Tabel 1 Karakteristik Responden

\begin{tabular}{|c|c|c|c|}
\hline \multicolumn{2}{|c|}{ Karakteristik Responden } & \multirow{2}{*}{$\begin{array}{c}\begin{array}{c}\text { Frekuensi } \\
\text { ( } \mathrm{N}=90 \text { orang) }\end{array} \\
22\end{array}$} & \multirow{2}{*}{$\begin{array}{c}\text { Persentase } \\
\text { (\%) } \\
24,4\end{array}$} \\
\hline Usia & 60-64 tahun & & \\
\hline & 65-69 tahun & 19 & 21,1 \\
\hline & $\geq 70$ tahun & 49 & 54,4 \\
\hline \multirow[t]{2}{*}{ Jenis kelamin } & Laki-laki & 36 & 40 \\
\hline & Perempuan & 54 & 60 \\
\hline \multirow[t]{3}{*}{ Tingkat pendidikan } & Rendah & 86 & 95,6 \\
\hline & Sedang & 4 & 4,4 \\
\hline & Tinggi & 0 & 0 \\
\hline \multirow[t]{3}{*}{ Status pernikahan } & Tidak menikah & 4 & 4,4 \\
\hline & Menikah & 57 & 63,3 \\
\hline & Duda/janda & 29 & 32,2 \\
\hline \multirow[t]{2}{*}{ Status pekerjaan } & Bekerja & 27 & 30,0 \\
\hline & Tidak bekerja & 63 & 70,0 \\
\hline \multirow[t]{2}{*}{ Penghasilan } & Dibawah UMK & 34 & 37,8 \\
\hline & Diatas UMK & 56 & 62,2 \\
\hline Riwayat Keluarga & Ada riwayat depresi & 2 & 2,2 \\
\hline Depresi & $\begin{array}{l}\text { Tidak ada riwayat } \\
\text { depresi }\end{array}$ & 88 & 97,8 \\
\hline Riwayat Penyakit & 0-2 penyakit & 83 & 92,2 \\
\hline Kronis & $>2$ penyakit & 7 & 7,8 \\
\hline \multirow[t]{2}{*}{ Status Depresi } & Depresi & 21 & 23,3 \\
\hline & Tidak depresi & 69 & 76,7 \\
\hline
\end{tabular}

\section{Karakteristik Riwayat Keluarga Depresi pada \\ Responden}

Dari hasil wawancara mengenai riwayat keluarga yang memiliki hubungan darah dengan responden yang memiliki riwayat depresi, ditemukan lebih banyak responden yang tidak memiliki riwayat keluarga yang menderita depresi yakni sebanyak 88 orang $(97,8 \%)$, sedangkan sisanya sebanyak 2 orang $(2,2 \%)$ memiliki riwayat tersebut.

\section{Karakteristik Penyakit Kronis pada Responden}

Berdasarkan hasil wawancara mengenai penyakit kronis yang dimiliki oleh responden, ditemukan lebih banyak responden yang hanya memiliki 0-2 jenis penyakit kronis yakni sebanyak 83 orang $(92,2 \%)$, sedangkan sisanya yakni sebanyak 7 orang $(7,8 \%)$ memiliki lebih dari dua jenis penyakit kronis. 


\section{Prevalensi Depresi}

Melalui kuesioner Geriatric Depression Scale (GDS) versi pendek dengan 15 pertanyaan digunakan untuk menilai status depresi responden, yang selanjutnya dikategorikan menjadi depresi (apabila skor akhir $\geq 5$ ) dan tidak depresi (apabila skor akhir 0-4). Berdasarkan hasil penelitian didapatkan bahwa responden yang mengalami depresi sebanyak 21 orang $(23,3 \%)$, sedangkan yang tidak mengalami depresi sebanyak 69 orang $(76,7 \%)$.

\section{Distribusi Status Depresi berdasarkan Usia}

Berdasarkan usia, proporsi kejadian depresi paling tinggi ditemukan pada kelompok usia 70 tahun ke atas yakni sebanyak 15 orang $(30,6 \%)$, diikuti oleh kelompok usia 65-69 tahun sebanyak 3 orang $(13,6 \%)$ dan kelompok usia 60-64 tahun sebanyak 3 orang (15,8\%). Hasil menunjukkan adanya kecenderungan peningkatan angka depresi seiring dengan pertambahan usia.

\section{Distribusi Status Depresi berdasarkan Jenis Kelamin}

Berdasarkan jenis kelamin proporsi depresi pada responden laki-laki lebih tinggi jika dibandingkan dengan responden perempuan. Dalam penelitian ini, ditemukan sebanyak 11 responden laki-laki $(30,6 \%)$ mengalami depresi, sedangkan responden perempuan yang mengalami depresi sebanyak 10 orang $(18,5 \%)$.

\section{Distribusi Status Depresi berdasarkan Tingkat Pendidikan}

Berdasarkan tingkat pendidikan, proporsi depresi hanya ditemukan pada kelompok responden yang berpendidikan rendah yaitu sebanyak 21 orang $(24,4 \%)$. Pada kelompok responden berpendidikan sedang dan tinggi tidak ada yang mengalami depresi.

Tabel 2 Distribusi Status Depresi berdasarkan Karakteristik Responden

\begin{tabular}{|c|c|c|c|c|c|}
\hline \multicolumn{2}{|c|}{ Karakteristik Responden } & \multicolumn{4}{|c|}{ Status Depresi } \\
\hline & & Depresi & $\%$ & Tidak Depresi & $\%$ \\
\hline \multirow[t]{3}{*}{ Usia } & 60-64 tahun & 3 & 13,6 & 19 & 86,4 \\
\hline & 65-69 tahun & 3 & 15,8 & 16 & 84,2 \\
\hline & $\geq 70$ tahun & 15 & 30,6 & 34 & 69,4 \\
\hline \multirow[t]{2}{*}{ Jenis kelamin } & Laki-laki & 11 & 30,6 & 25 & 69,4 \\
\hline & Perempuan & 10 & 18,5 & 44 & 81,5 \\
\hline \multirow[t]{3}{*}{ Tingkat pendidikan } & Rendah & 21 & 24,4 & 65 & 75,6 \\
\hline & Sedang & 0 & 0 & 4 & 100 \\
\hline & Tinggi & 0 & 0 & 0 & 0 \\
\hline \multirow[t]{3}{*}{ Status pernikahan } & Tidak menikah & 2 & 50 & 2 & 50 \\
\hline & Menikah & 11 & 19,3 & 46 & 80,7 \\
\hline & Duda/janda & 8 & 27,6 & 21 & 72,4 \\
\hline \multirow[t]{2}{*}{ Status pekerjaan } & Bekerja & 5 & 18,5 & 22 & 81,5 \\
\hline & Tidak bekerja & 16 & 25,4 & 47 & 74,6 \\
\hline \multirow[t]{2}{*}{ Penghasilan } & Dibawah UMK & 14 & 41,2 & 20 & 58,8 \\
\hline & Diatas UMK & 7 & 12,5 & 49 & 87,5 \\
\hline Riwayat Keluarga & $\begin{array}{ll}\text { Ada } & \text { riwayat } \\
\text { depresi } & \end{array}$ & 0 & 0 & 2 & 100 \\
\hline Depresi & $\begin{array}{l}\text { Tidak ada riwayat } \\
\text { depresi }\end{array}$ & 21 & 23,9 & 67 & 76,1 \\
\hline Riwayat Penyakit & $0-2$ penyakit & 19 & 22,9 & 64 & 77,1 \\
\hline Kronis & >2 penyakit & 2 & 28,6 & 5 & 71,4 \\
\hline
\end{tabular}

Distribusi Status Depresi berdasarkan Status Pernikahan

Berdasarkan status pernikahannya saat ini, responden yang berstatus menikah (masih punya pasangan) memiliki proporsi depresi paling tinggi, yakni sebanyak 11 responden (19,3\%), diikuti dengan responden yang berstatus duda/janda yang mengalami depresi sebanyak 8 orang $(27,6 \%)$ dan responden yang tidak menikah sebanyak 2 orang (50\%). 


\section{Distribusi Status Depresi berdasarkan Status Pekerjaan}

Berdasarkan status pekerjaan, responden yang tidak bekerja memiliki proporsi depresi yang lebih tinggi yakni sebanyak 16 orang $(25,4 \%)$, sedangkan di antara responden yang masih bekerja yang mengalami depresi hanya sebanyak 5 orang $(18,5 \%)$.

\section{Distribusi Status Depresi berdasarkan Penghasilan Keluarga Perbulan}

Responden yang memiliki penghasilan keluarga perbulan dibawah UMK memiliki proporsi depresi yang lebih tinggi yaitu sebesar 14 orang (41,2\%), sedangkan diantara responden yang berpenghasilan keluarga perbulan diatas UMK yang mengalami depresi hanya sebanyak 7 orang $(12,5 \%)$.

\section{Distribusi Status Depresi berdasarkan Riwayat Keluarga Depresi}

Responden yang tidak memiliki riwayat keluarga depresi memiliki proporsi depresi sebanyak 21 orang $(23,9 \%)$, sedangkan tidak ada responden yang memiliki riwayat keluarga depresi yang mengalami kejadian depresi.

\section{Distribusi Status Depresi berdasarkan Penyakit Kronis}

Sebanyak 19 orang $(22,9 \%)$ responden dengan lebih 0-2 penyakit kronis mengalami depresi. Proporsi ini lebih tinggi jika dibandingkan dengan responden dengan lebih dari 2 penyakit kronis yang mengalami depresi yakni sebanyak 2 responden $(28,6 \%)$.

\section{PEMBAHASAN}

Berdasarkan hasil penelitian ini, didapatkan prevalensi depresi pada lansia di wilayah kerja Puskesmas Tampaksiring I sebesar 23,3\%. Berdasarkan penelitian Suardana tahun 2011 di Kabupaten Karangasem ${ }^{8}$, angka ini tergolong rendah hampir setengahnya. Penelitian tersebut mendapatkan prevalensi kejadian depresi sebesar $41,7 \%$. Hal lain yang terdapat pada penelitian tersebut antara lain proporsi lansia yang tidak mengalami depresi $(75,6 \%)$ hampir tiga kali lipat lebih tinggi dibandingkan yang mengalami depresi. $\mathrm{Hal}$ ini sesuai dengan hasil penelitian yang dilakukan oleh Sri Woroasih pada tahun 1999, ${ }^{10}$ yang mengatakan bahwa pada studi komunitas, lebih banyak lansia yang tidak mengalami depresi dibandingkan dengan yang mengalami depresi. Salah satu faktor yang mendukung tingginya angka lansia tanpa depresi ini antara lain yaitu masih tingginya angka kegiatan sosial dalam hal ini upacara adat di daerah Tampaksiring (Bali pada umumnya). Dengan mengikuti kegiatan sosial ini, para lansia cenderung menjadi lebih aktif dalam bersosialisasi dengan sesamanya. Di samping itu, tempat penelitian ini juga dilaksanakan di pedesaan yang mana hal ini berhubungan dengan masih tingginya hubungan interpersonal antar sesama warga dalam hal beraktivitas. Disini warga saling bahu-membahu dalam menjalankan pekerjaan mereka. Dukungan sosial yang tinggi ini membuat para lansia akan merasa lebih nyaman dan bahagia, sehingga dapat menjauhkannya dari risiko depresi. Beberapa hal kontradiktif dalam penelitian ini antara lain dibandingkan dengan penelitian lain yang dilakukan oleh Dewi (2007, dalam Suardana 2011), ${ }^{8}$ angka depresi pada penelitian ini masih tergolong tinggi. Pada penelitian tersbut, tercatat prevalensi depresi hanya sebesar $6.5 \%$ beberapa hal yang dapat dijadikan pertimbangan tingginya angka depresi dibandingkan dengan penelitian tersebut antara lain tingginya angka lansia yang tidak bekerja secara tetap dan tingginya rata-rata umur lansia yang masuk dalam kategori umur 70 tahun keatas. Rendahnya tingkat pendidikan pada mayoritas lansia dalam penelitian ini $(95,6 \%)$ juga merupakan faktor pendukung tingginya angka depresi relatif terhadap penelitian tersebut. Di samping itu, banyak lansia yang tidak memiliki persiapan khusus di hari tua mereka dalam dalam menghadapi masa tua, sehingga hanya menyerahkan beban hidup pada anak dan kerabat yang pada beberapa kasus kurang mampu memenuhi kebutuhan hidup mereka akibat keterbatasan ekonomi dan waktu. ${ }^{8}$ Berdasarkan penghasilan keluarga perbulan sebagian besar responden $(62,2 \%)$ saat ini memiliki penghasilan keluarga perbulan diatas UMK. Sedangkan 37,8\% sisanya masih berada dibawah UMK. Hal ini sesuai dengan data dari Badan Pusat Statistik yang menyatakan pada September 2014 penduduk miskin di Indonesia mencapai 27,73 juta orang (10,96\% dari populasi). Hal ini mengindikasikan kesejahteraan masyarakat yang sudah lebih baik daripada keadaan sebelumnya dimana pada bulan Maret 2014 sebanyak 11,25\% dari populasi masih berada di bawah garis 
kemiskinan. Hal ini menjadi kemungkinan penyebab sebanyak $30 \%$ dari responden masih aktif bekerja untuk membantu membiayai keperluan sehari-hari, ataupun sekedar melengkapi kebutuhan primer keluarganya dengan bercocok tanam.

Riwayat keluarga depresi merupakan salah satu faktor resiko seseorang menderita depresi. Hal ini merupakan salah satu faktor pencetus menderita depresi kedepannya karena ambang tahan terhadap suatu stressor yang dapat menyebabkan depresi diturunkan dalam jumlah tertentu secara genetik. Pada penelitian ini didapatkan sebagian besar responden, yaitu sebanyak 88 responden $(97,8 \%)$ tidak memiliki keluarga dengan riwayat depresi. Sedangkan sisanya, yaitu 2 orang responden memiliki keluarga dengan riwayat depresi. Gatz (1992 dalam Blazer 2005) ${ }^{11}$ mengatakan bahwa pengaruh genetik atau keluarga terhadap munculnya gejala depresi adalah sangat minim, jadi tinggi rendahnya persentase seseorang dengan keluarga dengan riwayat depresi tidak harus selalu mencerminkan keadaan keluarga yang lain. Beberapa hal yang menyebabkan tingginya persentase responden tanpa riwayat keluarga yang memiliki gangguan depresi mungkin disebabkan oleh masih banyak kasus depresi yang belum terdiagnosis yang berhubungan dengan kondisi pedesaan tempat penelitian dilakukan. Rendahnya keluhan lansia terhadap gangguan mood dibanding keluhan fisik yang mereka rasakan yang juga turut berpengaruh terhadap outcome angka depresi kedepannya.

Dalam penelitian ini didapatkan sebagian besar responden yakni sebanyak 83 responden $(92,2 \%)$ hanya memiliki 0-2 jenis penyakit kronis yang telah didiagnosis oleh dokter. Pada penelitian ini, penyakit kronis didefinisikan sebagai penyakit yang diderita oleh responden yang telah didiagnosis oleh dokter dan telah diderita minimal selama tiga bulan. Lebih banyaknya jumlah responden yang hanya memiliki 0-2 penyakit dapat disebabkan oleh karena masih banyaknya responden yang belum pernah memeriksakan diri ke dokter sehingga penyakit kronis yang sebenarnya diderita responden belum terdeteksi/terdiagnosis.

Hasil analisis mengenai status depresi dalam penelitian ini diperoleh bahwa terdapat $15(30,6 \%)$ responden dalam kelompok umur diatas 70 tahun yang mengalami depresi dibandingkan dengan 3 responden $(13,6 \%)$ pada kelompok umur 60-64 dan
3 responden (15,8\%) pada kelompok umur 65-69 tahun yang mengalami depresi. Hasil ini menunjukan bahwa proporsi depresi semakin meningkat seiring dengan peningkatan usia. Dari data distribusi status depresi berdasarkan usia pada tabel 2 pun menunjukan peningkatan angka depresi sesuai dengan peningkatan usia. Hasil ini sesuai dengan penelitian yang dilakukan oleh Silvia (2010, dalam muna 2013) dan Wulandari yang menyatakan bahwa depresi memiliki korelasi dngan peningkatan usia. ${ }^{9,12}$ Strawbridge (2002) juga mengungkapkan bahwa lansia yang berusia diatas 70 tahun memiliki peluang menderita depresi 1,8 kali lebih tinggi dibandingkan usia yang lebih muda. ${ }^{13}$

Jenis kelamin merupakan faktor demografi lain yang berkaitan dengan status depresi. Dalam penelitian ini didapatkan hasil bahwa jumlah lansia laki-laki yang mengalami depresi lebih banyak bila dibandingkan jumlah lansia perempuan yang mengalami depresi. Dari tabel 2 dijabarkan dari 21 responden yang mengalami depresi, 11 merupakan laki-laki. Dari tabel ini juga dapat dilihat sebanyak $30.6 \%$ laki-laki dari seluruh responden laki-laki dibandingkan dengan $18,5 \%$ dari seluruh responden perempuan yang mengalami depresi. Hasil penelitian ini kurang cocok jika dibandingkan dengan penelitian yang dilakukan oleh Glaesmer tahun 2011. ${ }^{14}$ Seperti yang kita ketahui bersama, kebanyakan penelitian mengungkapkan bahwa angka depresi terjadi lebih tinggi di kalangan wanita daripada pria. Ketidakcocokan ini mungkin disebabkan karena di Bali menganut sistem paternalisme yaitu laki-laki berperan sebagai kepala keluarga. Hal ini dapat menyebabkan beban yang ditanggung oleh laki-laki menjadi lebih berat dan meningkatkan resiko terjadinya depresi.

Berdasarkan tingkat pendidikan, proporsi depresi hanya ditemukan pada kelompok responden yang berpendidikan rendah yaitu sebanyak 21 orang (24,4\%). Untuk kelompok dengan responden berpendidikan sedang dan tinggi, tidak ditemukan responden yang mengalami depresi. Hasil ini sesuai dengan penetilian yang dikerjakan oleh lliffe. ${ }^{15}$ Penelitian tersebut menjelaskan hubungan rendahnya tingkat pendidikan terkait dengan tingginya tingkat depresi.

Status pernikahan merupakan salah satu faktor yang menentukan outcome depresi pada lansia kedepannya. Hal ini berhubungan dengan rasa berbagi dan kasih sayang yang dibutuhkan oleh 
lansia. Untuk tingkat depresi ditinjau dari status pernikahan, didapatkan hasil hampir setengah dari responden yang tidak menikah (50\%) mengalami depresi, diikuti dengan kelompok duda janda dengan angka depresi sebesar $27.6 \%$ dari total responden dengan status duda/janda dan terakhir oleh kelompok lansia yang menikah dengan angka depresi sebesar 19,3\%. Hal ini sesuai dengan penelitian yang telah dilakukan oleh Carrera Campos di tahun 2014 yang menunjukan angka depresi lebih banyak dialami oleh seseorang yang tidak menikah. ${ }^{16}$ Ini disebabkan oleh karena seseorang yang berstatus tidak menikah atau duda atau janda beresiko hidup sendiri, dimana hidup sendiri juga merupakan faktor risiko terjadinya depresi pada lansia. Sidik et al juga menyatakan bahwa gangguan depresi lebih sering dialami seseorang yang bercerai atau berpisah dibanding dengan yang menikah. ${ }^{17}$

Dilihat dari persentase, penelitian ini memiliki korelasi dengan penelitian sebelumnya. Akan tetapi dilihat dari angka absolut, ada ketidakcocokan yang disebabkan oleh perbedaan mencolok jumlah dari responden per-kelompok yang mana 57\% dari responden dalam penelitian kami berstatus menikah. Karena perbedaan jumlah sampel perkelompok yang cukup mencolok kami menggunakan persentase untuk menarik kesimpulan dari analisis depresi menurut status pernikahan ini. Dari penjabaran ini dapat disimpulkan lansia yang masih memiliki pasangan hidup akan memiliki tempat untuk saling berbagi, mendukung dalam menghadapi masa tua, sehingga memiliki risiko depresi yang lebih rendah.

Dari segi status pekerjaan, angka depresi dalam penelitian ini didapatkan lebih tinggi pada lansia yang tidak bekerja, yakni sebanyak 16 orang $(25,4 \%)$, Sedangkan diantara responden yang masih bekerja yang mengalami depresi hanya sebanyak 5 orang $(18,5 \%)$. Hasil ini memiliki hubungan dengan hasil penelitian yang dilakukan oleh Suardana yang menyimpulkan mayoritas lansia yang tidak bekerja mengalami depresi. ${ }^{8}$ Bekerja atau memiliki aktivitas tetap merupakan salah satu bentuk perilaku hidup aktif. Hal ini berkaitan dengan penghasilan dan penghasilan sering dikaitkan dengan pemenuhan kebutuhan manusia. Dengan bekerja, seseorang dapat melakukan sesuatu untuk meningkatkan kualitas hidupnya dan meningkatkan interaksi sosialnya. Perilaku hidup aktif ini merupakan salah satu cara menghindari gangguan depresi. ${ }^{8}$ Beberapa faktor mempengaruhi terganggunya lansia dalam bekerja. Perubahan fisik dan mental yang terjadi pada seorang lansia sangat mempengaruhi produktivitas lansia dalam bekerja. Gangguan ini cenderung menyebabkan lansia tidak bekerja sehingga menyebabkan kurangnya prilaku hidup aktif yang mana berkaitan dengan tingginya waktu kosong termasuk dalam berinteraksi sosial yang mendorong rasa bosan dan jenuh sehingga dapat mengarahkan kearah depresi.

Penghasilan keluarga perbulan dibawah garis upah minimum regional/kabupaten dapat menjadi salah satu faktor risiko timbulnya depresi. Hal ini dikaitkan dengan sulitnya memperoleh kebutuhan primer dengan kualitas baik seperti pola makan teratur, sanitasi yang baik, dan perawatan kesehatan, apabila penghasilan keluarga responden berada dibawah garis standar penghasilan. Berdasarkan hasil penelitian yang diperoleh sebanyak 14 orang (41,2\%) dari lansia yang berpenghasilan keluarga dibawah UMK mengalami kejadian depresi. Hal ini sesuai dengan penelitian yang dilakukan oleh Teresia pada tahun 2011 yang memperoleh hasil bahwa diantara lansia yang berpenghasilan keluaga rendah sebanyak 43,9\% mengalami depresi. ${ }^{18}$ Hasil serupa juga didapatkan pada penelitian Strawbridge yang mengatakan lansia dengan gangguan ekonomi berpeluang menderita depresi 2,4 kali dibandingkan dengan yang tidak memiliki masalah keuangan. ${ }^{13}$ Dengan kata lain pendapatan yang rendah merupakan faktor risiko terjadinya depresi. ${ }^{19}$

Riwayat keluarga depresi, berkaitan dengan gangguan depresi yang mungkin diderita oleh keluarga yang memiliki hubungan darah. Dari hasil penelitian status depresi berdasarkan riwayat keluarga depresi, didapatkan sebanyak 21 responden mengalami depresi pada kelompok responden tanpa riwayat keluarga depresi dibandingkan dengan 0 responden yang mengalami depresi dari keluarga dengan riwayat keluarga depresi. Hasil penelitian ini tidak sesuai dengan teori yang dikemukakan Gatz (1992, dalam Blazer 2005). ${ }^{11}$ Perbedaan dari hasil ini mungkin disebabkan oleh tidak bermaknanya hubungan antara riwayat anggota keluarga yang menderita depresi dengan kejadian depresi di Tampaksiring. Hal ini didukung oleh Suardana (2011) yang menyatakan tidak sesuainya hasil pada variabel ini 
disebabkan oleh depresi yang terjadi lebih dipengaruhi oleh faktor perilaku, lingkungan dan pelayanan kesehatan, bukan genetik murni. ${ }^{8}$

Status kesehatan merupakan salah satu faktor pencetus depresi pada lansia. Telah banyak penelitian yang meneliti mengenai kondisi status kesehatan seseorang dengan angka depresi di populasi. ${ }^{20}$ Penyakit fisik dapat mengakibatkan menurunnya kemampuan fisik dan fisiologis seseorang sehingga dapat menurunkan seseorang untuk beraktivitas seperti biasanya baik dalam bekerja maupun melakukan kegiatan fisik lainnya. ${ }^{21}$ Dalam penelitian ini ditemukan bahwa persentase depresi pada lansia dengan lebih dari dua jenis penyakit kronis lebih tinggi dibandingkan lansia dengan 0-2 jenis penyakit saja $(28,16 \%$ berbanding $22,9 \%$ ). Hasil ini sudah sesuai dengan penelitian yang dilakukan Wulandari (2011) dan Chapmann (2005) yang menyatakan bahwa kondisi multipatologis erat berhubungan dengan depresi dan terdapat hubungan timbal balik antara penyakit kronis dan depresi. ${ }^{9,20}$ Kelemahan pada penelitian dilihat dari variabel ini adalah angka tersebut tidak sesuai dengan penelitian sebelumnya jika dibandingkan menggunakan angka absolut. Hal ini disebabkan oleh karena perbedaan yang signifikan dalam jumlah responden antara responden dengan kelompok yang memiliki 0-2 penyakit dengan responden dalam kelompok lebih dari 2 penyakit.

\section{SIMPULAN}

1. Prevalensi depresi pada lansia di wilayah kerja Puskesmas Tampaksiring I adalah sebesar 23,3\%.

2. Prevalensi lansia dengan depresi cenderung lebih tinggi pada lansia laki-laki, kelompok usia 70 tahun ke atas, berpendidikan rendah, tidak bekerja, berpenghasilan perbulan rendah, tidak menikah, memiliki penyakit kronis $>2$, dan tidak memiliki riwayat keluarga depresi.

\section{Kelemahan Penelitian}

1. Hanya terdapat satu posyandu lansia yang aktif diantara 33 banjar/dusun di wilayah kerja Puskesmas Tampaksiring I. Hal ini mengakibatkan pendataan lansia yang kurang baik pada program lansia di Puskesmas Tampaksiring I. Sehingga peneliti menggunakan data berupa kumpulan kartu keluarga yang dimiliki oleh ketua dusun/kelihan banjar, yang mengakibatkan adanya kemungkinan lansia pada banjar tersebut yang tidak termasuk dalam sampling frame.
2. Sehubungan dengan pengumpulan data mengenai penyakit kronis, terdapat kemungkinan adanya lansia yang telah memiliki penyakit kronis namun belum terdiagnosis karena belum memeriksakan diri ke dokter.

3. Sehubungan status depresi responden dengan GDS, kemungkinan terdapat pertanyaan yang kurang dimengerti oleh responden mengingat sebagian besar responden berlatar belakang pendidikan yang tergolong rendah dan usia tua menyebabkan beberapa kendala komunikasi dan bahasa. Hal-hal tersebut dapat menyebabkan jawaban kuesioner yang diperoleh tidak sesuai dengan jawaban sebenarnya.

\section{SARAN}

1. Berkaitan dengan adanya $23,3 \%$ penduduk lansia di wilayah kerja Puskesmas Tampaksiring I yang mengalami depresi. Hal ini mengindikasikan perlunya perhatian lebih pada lansia, utamanya lansia yang memiliki faktor risiko seperti diuraikan diatas.

2. Keaktifan posyandu lansia yang telah ada di masing-masing banjar perlu ditingkatkan dan diaktifkan kembali, kegiatan seperti pemeriksaan kesehatan maupun menghadirkan acara yang menarik di tiap kegiatan posyandu lansia dapat meningkatkan minat keikutsertaan lansia pada program tersebut.

3. Para lansia sebaiknya lebih aktif dalam mengikuti kegiatan posyandu lansia agar faktor risiko terkait depresi bisa di deteksi lebih awal sekaligus mencari status depresi lansia tersebut.

4. Diharapkan dilakukan penelitian lebih lanjut mengenai faktor-faktor yang dapat meningkatkan risiko depresi pada lansia di wilayah kerja Puskesmas Tampaksiring I.

\section{DAFTAR PUSTAKA}

1. Buletin Jendela Data dan Informasi Kesehatan RI. Gambaran Kesehatan Lanjut Usia di Indonesia. Indonesia; 2013.

2. Martono, H. Gerakan Nasional Pemberdayaan Lanjut Usia. Jakarta: Gemari; 2008.

3. BPS Provinsi Bali. Statistik Daerah Provinsi Bali Tahun 2012. Denpasar: Badan Pusat Statistik Provinsi Bali; 2013.

4. Profil Unit Pelayanan Terpadu Kesehatan Masyarakat Tampaksiring I Tahun 2013-2014. Program Posyandu Lansia. Tampaksiring; 2014. 
5. Soejono, C.H. Pedoman Pengelolaan Kesehatan Pasien Geriatri: untuk Dokter dan Perawat. Jakarta: Penerbit FK UI; 2006.

6. Ausrianti, R. Hubungan Antara Tingkat Depresi Dengan Tingkat Kemampuan Melaksanakan Aktivitas Dasar Sehari-Hari Pada Lanjut Usia Di Pstws Abai Nan Aluih Sicincin; 2010. Available from URL : http://repository.unand.ac.id/18336/. Accessed: April 16, 2015.

7. Smoliner, C. Malnutrition and depression in the institutional eldely. The British Journal of Nutrition 2009; 02 (11) 1663-7.

8. Suardana, I.W. Hubungan Faktor Sosiodemografi, Dukungan Sosial, dan Status Kesehatan dengan Tingkat Depresi pada Agregat Lanjut Usia di Kecamatan Karangasem, Kabupaten Karangasem, Bali. Fakultas IImu Keperawatan Universitas Indonesia; 2011. Available from URL: http://lib.ui.ac.id/file?file=digital/201282773-T20Wayan\%20Suardana.pdf. Accessed: April 20, 2015.

9. Wulandari, Sekar. Kejadian dan Tingkat Depresi pada Lanjut Usia : Studi perbandingan di panti wreda dan komunitas; 2011. Available from URL: http://eprints.undip.ac.id/32877/1/Ayu Fitri.pdf

Accessed: April 22, 2015

10. Woroasih, Sri. Hubungan Stressor Psikososial dan Dukungan Sosial dengan Depresi Pada Lanjut Usia; 1999. Available from URL : http://eprints.undip.ac.id/14287/ Accessed: April 18, 2015.

11.Blazer, Dan. Origins of Depression in later life. Cambridge University Press, North Carolina 2005; pp: 35, 1-12.

12. Muna Nailil. Hubungan Antara Karakteristik Dengan Kejadian Depresi pada Lansia di Panti Werda Pelkris Pengayoman Kota Semarang. Semarang; 2013. Available from URL: http://www.google.com/url?q=http://surat.stikeste logorejo.ac.id/e-journal/index.php/

ilmukeperawatan /article/ download/ 132/157\&sa=U\&ei=iYlHVdXWL

MnjuQTO14EI\&ved=0CCQQFjAD\&sig2=kO1XRNxWp YLIt3RIDdTHWg\&usg=AFQjCNGFmJqOHeoVdZyz5Vzj kRvfLqP6Pg Accessed: April 20, 2015.

13. Strawbridge W.J., Deleger S., Roberts E.R., Kaplan G.A. Physical activity reduce the risk of subsequent depression for older adult; American Journal of Epidemiology 2002; Vol 156 No 4 p 328-334;
Available from URL: http:// aje.oxfordjournals.org/content/156/4/328 .full. pdf+ html. Accessed: May 2, 2015.

14. Glaesmer, H. Age- and Gender-Specific Prevalence and Risk Factor for Depressive Symptoms in the Elderly: a Population-Based Study; 2011. Available from URL :

http://www.ncbi.nlm.nih.gov/pubmed/21729425 Accessed: April 22, 2015.

15. Iliffe, S. Recognition and Response: Approaches to Late-Life Depression and Mental Health Problem in Primary Care; 2009. Available from URL: http://www.emeraldinsight.com/doi/pdfplus/10.11 08/14717794200900003 Accessed: April 22, 2015.

16. Campos, Carrera. Prevalence of Depressive Symptoms and Associated Factors among Institutionalized Elderly; 2014. Available from URL: http://www.scielo.br/pdf/ape/v27n3/en 19820194-ape-027-003-0208.pdf Accessed : April 24, 2015

17. Sidik S.M. et al. Factors Associated with Depression Among Elderly Patients in a Primary Health Care Clinic in Malaysia. Malaysia; 2003. Available from URL : http://www. apfmj-archive.com /afm2.3/afm 80.pdf. Accessed April 17, 2015.

18. Teresia, N.P., et al. Prevalensi dan Faktor Risiko Depresi pada Lansia di Desa Selulung Kecamatan Kintamani Kabupaten Bangli tahun 2014. Bagian Psikiatri Fakultas Kedokteran Universitas Udayana. Denpasar; 2014.

19. Mauk K.L. Gerontological nursing: competencies for care. $\left(2^{\text {nd }}\right.$ ed). Canada: Jones and Bartlett Publishers; 2010.

20. Chapman, Daniel et al. The Vital Link Between Chronic Disease and Depressive Disorders ; 2005. Available from URL : http://origin.glb.cdc.gov /pcd/issues/2005/jan/04 0066.htm Accessed : April 23, 2015

21. Wurff, Van der. (2004). Prevalence and Risk-Factor for Depression in Elderly Turkish and Moroccan Migrants in the Netherlands. Available from URL: http://www.jad-journal.com/article/S01650327(04)00172-7/abstract Accessed:April 24, 2015.

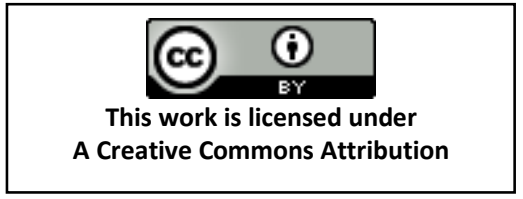

